\title{
Distribution of Arbuscular Mycorrhizae Associated with Coconut and Arecanut Based Cropping Systems
}

\author{
K. Ambili $\cdot$ George V. Thomas $\cdot$ P. Indu • \\ Murali Gopal · Alka Gupta
}

Received: 30 June 2012/ Accepted: 26 September 2012/Published online: 4 November 2012

(C) NAAS (National Academy of Agricultural Sciences) 2012

\begin{abstract}
Mycorrhizal fungi are widespread in agricultural systems and are especially relevant for organic agriculture. A study was conducted to assess diversity in the arbuscular mycorrhizal (AM) fungi associated with coconut and arecanut intercropping systems of Kasaragod and Thiruvananthapuram districts of Kerala. Mycorrhizal parameters like spore density, root colonization, species richness, and relative occurrence of species were recorded. Coconut cropping system was found to be densely vegetated with diverse AM fungi, Glomus spp., Gigaspora spp., and Acaulospora spp. The diversity of fungal species was found to be maximum in the high density multiple species cropping system plot of CPCRI, Kasaragod with coconut as the main crop and banana, pepper as intercrops and least in farmers' plot of Mogral Puthur, Kasaragod with arecanut as main crop and banana as the intercrop. A total of fourteen AM fungi were identified from coconut and arecanut intercropping systems. Glomus aggregatum, Funneliformis mosseae, and Rhizophagus fasiculatum were observed in both the cropping systems studied. Among the six edaphic factors analysed, an inverse relationship of mycorrhizal population with soil $\mathrm{pH}$ and soil phosphorous was observed. An abundance of P-solubilizers, fluorescent Pseudomonas spp., N-fixers, Bacillus spp., and Trichoderma spp. were observed in the rhizosphere, with Bacillus spp. showing the maximum association with AM fungi. The higher AMF colonization in coconut cropping system imply that the AM fungi colonization is primarily dependent on the host plant rather than the climatic/edaphic components of an area.
\end{abstract}

Keywords Coconut intercropping system · Arecanut intercropping system · AMF · Glomus spp. · Gigaspora spp. · Acaulospora spp.

\section{Introduction}

Coconut and arecanut are the important plantation crops grown in the state of Kerala. The plant-microbial relationship can play a very important role in crop performance. Often the relationship is symbiotic. Among the active microorganisms in the soil there are three main groups that are more or less directly involved in the palm's nutrient supply: nitrogen-fixing bacteria in the rhizosphere, phosphate solubilizing fungi, and arbuscular mycorrhizal fungal association that help in the absorption of phosphorus and other

K. Ambili $(\bowtie) \cdot$ G. V. Thomas · P. Indu · M. Gopal · A. Gupta Microbiology Section, Central Plantation Crops Research Institute, Kudlu P.O., Kasaragod 671124, Kerala, India

e-mail: ambiliharidas@gmail.com immobile elements. The symbiosis of plant with arbuscular mycorrhizal (AM) fungi is the widest spread symbiosis in natural ecosystems [11]. AM are associations where Glomeromycete fungi produce arbuscules, hyphae, and vesicles within root cortex cells [23]. Studies on microbial interactions in the mycorrhizosphere have focused on exotic populations of beneficial soil micro-organisms, plant growth promoting rhizobacteria [15], and phosphate- solubilizing bacteria [30]. Relationships between native soil microbe communities and AM fungi have received less attention [19] and it is not known whether members of a native soil bacterial flora show preference for native or exotic AM fungi. Different bacterial populations may establish themselves under the influence of different plant-AM fungus combinations [25]. Control of AM fungi over the nature and quantity of root exudates and subsequent competition between 
bacteria and AM fungi for this $\mathrm{C}$ source may determine the size and composition of bacterial populations in the rhizosphere [5]. There are also reports on the bacteria associated with AMF spores which have been found in the cytoplasm of AMF spores [2].

AM symbiosis can improve host responses to other environmental limitations, like drought, salinity, pollutants, erosion, and infection by pathogenic fungi [15]. AM fungi in symbiotic association with plants affect the hormone level; increase the level of cytokinins [1] and alter level of gibberellins and abscissic acid.

Arbuscular mycorrhizal associations have been well reported in palms, such as Cocos nucifera L. [29], arecanut [3], and, more recently in some tropical palms [10] under natural conditions.

In India, a number of fungi belonging to four genera viz., Glomus, Gigaspora, Sclerocystis, and Acaulospora have been found to form mycorrhizal associations with coconut [9]. The occurrence of a mixed population of AM has been commonly recorded from the coconut rhizosphere soils. Research on genotypic dependency of AMF in coconut revealed higher colonization rate in tall varieties compared to dwarf ones [28]. The quantitative and qualitative distribution of AMF also varied in response to a single crop or a combination of intercrops [21]. Present study focused on the distribution of arbuscular mycorrhizae in coconut and arecanut based cropping systems. The main aim of the study was to compare the species richness and diversity of AMF within the cropping systems and also to enumerate the plant beneficial micro-organisms in the rhizosphere of the plants.

\section{Materials and Methods}

Study Site and Sampling

Samples were collected from farmers' fields of coconut and arecanut based cropping systems of Kasaragod and Thiruvanathapuram districts to study the mycorrhizal spore load as well as root colonization.

Rhizospheric soil samples as well as root bits were collected to study the mycorrhizal association. Three replications per crop from each cropping system were analysed. Samples were collected from a soil depth of 0-25 cm from the rhizosphere of each crop, and stored in polyethylene bags.

\section{Rhizospheric Edaphic Features}

Physico-chemical parameters of the soil samples namely soil $\mathrm{pH}$ (Eutech instruments $\mathrm{pH}$ tutor), Electrical conductance (Eutech instruments), Organic carbon [32], Soil available phosphorous [4, 17] available potassium [8], and Nitrogen were estimated [12].

\section{Mycorrhizal studies}

Isolation of arbuscular mycorhizal spores was done by wet sieving decanting technique [7]. The identification was based on spore color, size, surface ornamentation, and wall structure with reference to the description and pictures provided by International Collection of Vesicular and Arbuscular Mycorrhizal Fungi (http://invam. caf.wvu.edu) and the original species descriptions [24]. Roots were stained for mycorrhizal infection [20]. AMF structures like vesicles and hyphae were recorded. Percentage of root colonization was calculated using the formula.

Frequency of root colonization

$$
=\frac{\text { Number of root bits having colonization }}{\text { Number of root bits observed }} \times 100
$$

Analysis of Soil Microflora

Rhizospheric soil samples were enumerated for the presence of beneficial microbes. Population estimation was done by plate count method. Soil samples were serially diluted and pour plated on Jenson's agar, Pikovskya's agar, Kings B, Nutrient agar and Trichoderma-specific medium for the isolation of $\mathrm{N}$-fixers, P-solubilizers, fluorescent Pseudomonas spp., Bacillus spp., and Trichoderma spp., respectively.

Data analysis

Pearson's correlation analysis was used to relate AMF spore load and frequency of root colonization with edaphic factors under each cropping systems. The statistical analysis was based on significant levels of $P<0.05$. The relationship between mycorrhizal fungi and soil microflora were also analysed.

The diversity of AM fungi in the cropping systems was assessed based on diversity indices

Simpsons index $(\mathrm{Ds})=1-\left(\sum \mathrm{ni} 2-\mathrm{N}\right) / \mathrm{N}(\mathrm{N}-1)$

Shannons index $(\mathrm{Hs})=\mathrm{NC}\{(\mathrm{N} \log 10 \mathrm{~N})$

$$
\left.-\sum \text { ni } / \log 10 \text { ni }\right\}
$$

where, $\mathrm{C}=3.321929$ (constant used in converting log 10 to $\log 2$ ). "ni" is the number of species in the 'ith' species and " $\mathrm{N}$ " is the total number of individual [14] 
Table 1 Geographical position, crops cultivated, and fertilizer input details of the study sites

\begin{tabular}{llll}
\hline Location & Geographical coordinates & Intercrops & Fertilizer input \\
\hline Coconut cropping system & & & \\
HDMSCS, CPCRI, Kasaragod & $12^{\circ} 31^{\prime} 32^{\prime} \mathrm{N}, 74^{\circ} 58^{\prime} 4^{\prime \prime} \mathrm{E}$ & Pepper, banana, pineapple & Vermicompost and husk burial \\
Patena 1, Kasaragod & $12^{\circ} 15^{\prime} 0^{\prime} \mathrm{N}, 75^{\circ} 6^{\prime} 0^{\prime} \mathrm{E}$ & Banana & Cow dung \\
Patena 2, Kasaragod & $12^{\circ} 15^{\prime} 18^{\prime \prime} \mathrm{N}, 75^{\circ} 8^{\prime} 13^{\prime \prime} \mathrm{E}$ & Banana, pepper & Cow dung \\
Azad Nagar, Kasaragod & $12^{\circ} 33^{\prime} 13^{\prime \prime} \mathrm{N}, 74^{\circ} 57^{\prime} 39^{\prime \prime} \mathrm{E}$ & Banana & Green leaf manure \\
Neerchal, Kasaragod & $12^{\circ} 35^{\prime} 0^{\prime \prime} \mathrm{N}, 75^{\circ} 2^{\prime} 0^{\prime \prime} \mathrm{E}$ & Banana, pepper & Cow dung \\
Velanad, Thiruvananthapuram & $8^{\circ} 34^{\prime} 0^{\prime \prime} \mathrm{N}, 77^{\circ} 3^{\prime} 0^{\prime \prime} \mathrm{E}$ & Banana, pepper & Cow dung \\
Pulippara, Thiruvananthapuram & $8^{\circ} 46^{\prime} 4^{\prime \prime} \mathrm{N}, 76^{\circ} 57^{\prime} 9^{\prime \prime} \mathrm{E}$ & Banana & Cow dung \\
Arecanut cropping system & & & Cow dung \\
Mogral puthur, Kasaragod & $12^{\circ} 33^{\prime} 18.7^{\prime}, \mathrm{N}^{\circ} 54^{\circ} 57^{\prime} 43.08^{\prime} \mathrm{E}$ & Banana & Cow dung \\
Keloth, Kasaragod & $12^{\circ} 23^{\prime} 0^{\prime} \mathrm{N}, 75^{\circ} 6^{\prime} 0^{\prime \prime} \mathrm{E}$ & Banana & Green leaf manure \\
Neerchal, Kasaragod & $12^{\circ} 35^{\prime} 0^{\prime \prime} \mathrm{N}, 75^{\circ} 2^{\prime} 0^{\prime \prime} \mathrm{E}$ & Banana, pepper, rasna, cardamom & Green leaf manure \\
Veliyamangalam, Thiruvananthapuram & $8^{\circ} 46^{\prime} 4^{\prime \prime} \mathrm{N}, 75^{\circ} 54^{\prime} 9^{\prime \prime} \mathrm{E}$ & Banana & Green leaf manure \\
Kumbara, Thiruvananthapuram & $8^{\circ} 46^{\prime} 4^{\prime \prime} \mathrm{N}, 75^{\circ} 54^{\prime} 8^{\prime \prime} \mathrm{E}$ & Banana & \\
\hline
\end{tabular}

HDMSCS High Density Multiple Species Cropping System

Frequency of occurrence (\%)

$=\frac{\text { Number of soil samples possessing spores of a particular species }}{\text { Total }}$

$$
\times 100 \quad \text { Total number of samples analysed }
$$

Relative abundance (\%)

$$
=\frac{\text { No of spores of particular species }}{\text { Total number of spores }} \times 100
$$

\section{Results and Discussion}

Coconut and arecanut based cropping systems of two districts of Kerala were studied for their arbuscular mycorrhizal distribution. The details of the sampling site along with its nutrient management practices is furnished in Table 1. The analysis of soil physico- chemical and mycorrhizal parameters are given in Table 2. Arbuscular mycorrhizal abundance were observed in 93 soil samples with a spore load, ranging from $33.83 \pm 10.84$ to $154.5 \pm 7.01$ spores $/ 10 \mathrm{~g}$ soil. All the plant roots observed were mycorrhizal except in arecanut at Mogral Puthur. Pearson's correlation of mycorrhizal spore load with root colonization and soil edaphic factors is represented in Table 3. Frequency of root colonization was found to be negatively correlated with mycorrhizal spore load in majority of cropping systems studied. Among the six rhizospheric edaphic factors analysed, soil $\mathrm{P}$ and soil $\mathrm{pH}$ was found to have a negative correlation with spore load. Total organic carbon content and electrical conductance showed insignificant correlation; however spore load at Patena plot was found to be negatively correlated with electrical conductance at $P \leq 0.05$. Total Nitrogen content was found to be negatively correlated with frequency of root colonization with a significant relation at
Keloth. Soil K is often reported to have a stimulatory effect on AM fungi variables [18] and a minimum soil $\mathrm{K}$ is often prerequisite for mycorrhizal colonization. However, present data showed that mycorrhizal parameters were independent of available potassium.

\section{AM fungi and Beneficial Microflora}

Enumeration of rhizospheric soil samples showed an abundance of soil microflora. Relation between AMF and beneficial microflora is represented in Table 4. Earlier works have reported the presence of different functional groups of bacteria such as nitrogen-fixing bacteria [27], plant growth promoting rhizobacteria, phosphate-solubilizing bacteria [13] associated with the rhizosphere of different plants colonized by AMF [25]. Some of the N-fixing, Bacillus spp., fluorescent Pseudomonas spp., Trichoderma spp., and P-solubilizers obtained in this study site are shown in Fig. 1. In coconut cropping system, a significant correlation could not be drawn for the beneficial microflora and AMF population. However, in arecanut cropping system, a negative correlation existed in AMF population with Trichoderma spp., fluorescent Pseudomonas spp., and nitrogen fixers. A positive correlation was observed for P-solubilizers. Studies have reported an increase in P-solubilizers in arecanut cropping system with increase in intercrops [22].

\section{Colonization and Spore Density}

AMF association in the cropping system was assessed by spore density (spore load) in the rhizospheric soil and by 
Table 2 Soil edaphic factors and mycorrhizal parameters

\begin{tabular}{lcccccccc}
\hline Location & $\mathrm{pH}$ & $\mathrm{OC}(\%)$ & $\mathrm{N}(\%)$ & $\mathrm{P}(\mathrm{ppm})$ & $\mathrm{K}(\mathrm{ppm})$ & $\mathrm{EC}(\mu \mathrm{s})$ & ${\text { Spore load10 } \mathrm{g}^{-1}}^{\mathrm{F}(\%)}$ \\
\hline HDMSCS, CPCRI & $5.43 \pm 0.3$ & $0.84 \pm 0.4$ & $0.14 \pm 0.7$ & $41.4 \pm 6.7$ & $20.5 \pm 9.1$ & $44.15 \pm 7.5$ & $56.83 \pm 10.83$ & $59.3 \pm 5.2$ \\
Patena & $5.58 \pm 0.1$ & $0.52 \pm 0.2$ & $0.11 \pm 0.1$ & $20.5 \pm 0.7$ & $21.6 \pm 3.7$ & $40.14 \pm 1.2$ & $40.14 \pm 1.15$ & $69.5 \pm 14.5$ \\
Patena plot 2 & $5.90 \pm 0.1$ & $1.2 \pm 0.2$ & $0.16 \pm 0.1$ & $54.86 \pm 15.7$ & $208.67 \pm 27.7$ & $226.6 \pm 57.5$ & $48.66 \pm 10.16$ & $64.2 \pm 7.03$ \\
Azad Nagar & $5.15 \pm 0.2$ & $0.64 \pm 0.3$ & $0.1 \pm 0.2$ & $24.81 \pm 1.6$ & $167.16 \pm 6.1$ & $84.4 \pm 8.9$ & $154.5 \pm 7.01$ & $77.2 \pm 2.9$ \\
Neerchal & $5.34 \pm 1.8$ & $2.3 \pm 0.9$ & $0.28 \pm 0.1$ & $32.7 \pm 13.8$ & $51.7 \pm 21.6$ & $481.3 \pm 90.3$ & $60.33 \pm 10.33$ & $57.7 \pm 9.62$ \\
Velanad & $4.02 \pm 0.1$ & $1.60 \pm 4.8$ & $0.085 \pm 0.2$ & $91.5 \pm 30.5$ & $13.52 \pm 0.5$ & $24.98 \pm 12.5$ & $59.98 \pm 17.66$ & $61.11 \pm 18.3$ \\
Pulippara & $4.76 \pm 2.6$ & $2.2 \pm 2.0$ & $0.17 \pm 0.1$ & $0.17 \pm 0.1$ & $17.3 \pm 14.8$ & $49.84 \pm 11.3$ & $50.33 \pm 33.66$ & $56.4 \pm 23.3$ \\
Mogral Puthur & $7.00 \pm 1.1$ & $1.12 \pm 1.2$ & $0.15 \pm 0.3$ & $22.65 \pm 10.6$ & $28.32 \pm 24.7$ & $118.11 \pm 106.7$ & $33.83 \pm 10.84$ & - \\
Keloth & $5.3 \pm 0.8$ & $1.61 \pm 1.0$ & $0.191 \pm 0.2$ & $21.2 \pm 28.1$ & $50.5 \pm 24.8$ & $109.03 \pm 45.1$ & $33.33 \pm 34.17$ & $15 \pm 0.34$ \\
Neerchal & $5.29 \pm 1.3$ & $0.766 \pm 0.9$ & $0.135 \pm 0.2$ & $35.18 \pm 25.3$ & $23.7 \pm 20.5$ & $129.05 \pm 47.7$ & $68.33 \pm 15.12$ & $57.16 \pm 56.46$ \\
Veliyamamgalam & $4.82 \pm 1.5$ & $0.83 \pm 1.0$ & $0.08 \pm 0.1$ & $0.063 \pm 0.1$ & $50.04 \pm 24.8$ & $144.73 \pm 72.7$ & $44.5 \pm 37.5$ & $39 \pm 14.85$ \\
Kumbara & $4.32 \pm 1.6$ & $0.99 \pm 2.4$ & $0.19 \pm 0.1$ & $78.3 \pm 68.3$ & $20.3 \pm 9.03$ & $93.4 \pm 5.1$ & $44.5 \pm 37.15$ & $34.5 \pm 14.5$ \\
\hline
\end{tabular}

HDMSCS high density multiple species cropping system, $O C$ organic carbon, $N$ Total Nitrogen, $P$ available phosphorous, $K$ Available potassium, $E C$ Electrical conducatance, $F \%$ Frequency of root colonization

Table 3 Pearsons correlation analysis of mycorrhizal spore load with root colonization and edaphic factors
* Significant at $P<0.05$

root colonization characterized by arbuscules, vesicles and hyphae. Root colonization percentage in coconut cropping system was the maximum at Azad Nagar (77.76 \pm 2.96$)$ and least at Patena plot $2(48.6 \pm 10.16)$. In arecanut cropping system, the maximum spore load was observed in Keloth plot $(58.33 \pm 15.2)$. The fungal spore density ranged from 40.4 to 154.5 spores per $10 \mathrm{~g}$ in coconut cropping system and a range of 33-44.5 spores per $10 \mathrm{~g}$ soil in arecanut cropping system. There are many factors that could affect spore density in a given host rhizosphere. Values for arbuscular mycorrhizal fungal spore density have varied greatly in previous reports [31].

\section{AMF Species Richness and Diversity}

Distribution of AM fungal species in coconut and arecanut cropping systems of two different districts of Kerala are represented in the Table 5. Species richness was the maximum at HDMSCS plot. AM fungal diversity varied with difference of sites (Table 5, 6). Most of the spore morphotypes were common to all sites, and few were specific. Altogether 14 AMF species (Fig. 2) were identified from 93 samples analysed. All spores belonged to the Glomineae order, represented by Glomaceae, Claroideoglomeraceae, Diversisporaceae, Acaulosporaceae, and Gigasporaceae families. Simpson's diversity index (Ds) and Shannon's diversity index $(\mathrm{Hs})$ in coconut cropping system was in the range of $0.89-0.98$ and 1.9-4.25, respectively. In arecanut cropping system, the index value of "Ds" and "Hs" ranged from 0.81 to 0.93 and 1.39 to 3.44 , respectively. The variation in AM fungal diversity in rhizosphere soil of a particular plant in different locations may be due to the influence of adjoining plants [30, 31]. Earlier studies have reported the occurrence of Glomus and Acaulospora spp. in coconut 
Table 4 Correlation analysis of AMF with other rhizosphere microflora

\begin{tabular}{llll}
\hline Location & P_solubilizers & $\begin{array}{l}\text { Fluorescent } \\
\text { Pseudomonas spp. }\end{array}$ & Trichoderma spp. \\
\end{tabular}

\begin{tabular}{lccrrr}
\hline Coconut cropping system & & & & \\
HDMSCS & -0.47 & 0.23 & -0.39 & 0.15 & -0.32 \\
Patena plot 1 & 0.21 & -0.05 & -0.30 & 0.81 & -0.61 \\
Patena plot 2 & 0.35 & -0.33 & 0.07 & 0.33 & 0.23 \\
Azad Nagar & 0.52 & 0.10 & 0.73 & -0.65 & -0.64 \\
Neerchal & -0.59 & - & 0.13 & 0.58 & 0.79 \\
Velanad & -0.60 & - & -0.13 & 0.23 & -0.02 \\
Pulippara & -0.16 & - & 0.16 & 0.29 & 0.07 \\
Arecanut cropping system & -0.58 & 0.49 & & & \\
Mogral Puthur & 0.74 & -0.22 & 0.34 & 0.08 & 0.15 \\
Keloth & 0.83 & -0.04 & -0.23 & 0.66 & -0.01 \\
Neerchal & 0.45 & 0.66 & 0.35 & 0.04 & 0.69 \\
Veliyamangalam & 0.12 & -0.42 & -0.87 & -0.29 & -0.40 \\
Kumbara & & & -0.78 & -0.70 & 0.40 \\
\hline
\end{tabular}
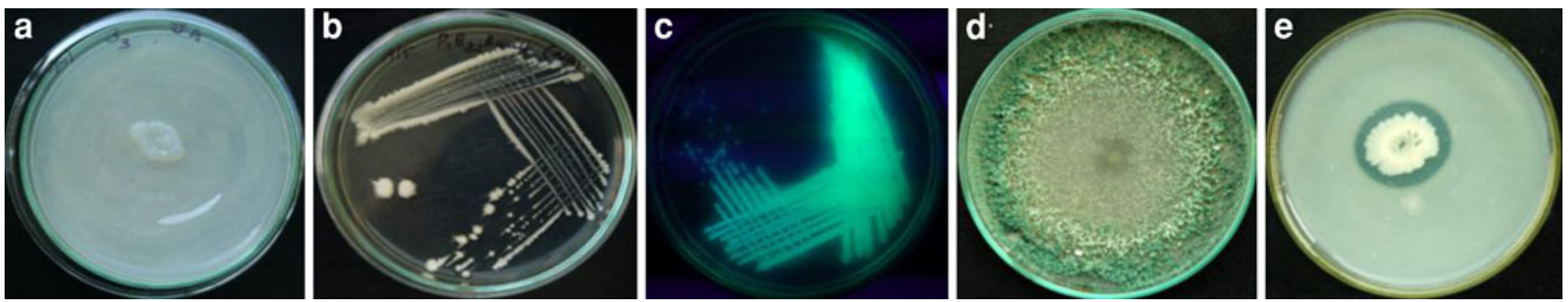

Fig. 1 Rhizosphere microflora. a Growth of N-fixer on Nitrogen free media, Banana rhizosphere; ACS,Veliyamangalam. b Bacillus sp., Banana rhizosphere, CCS, Patena 1. c fluorescent Pseudomonas sp.,

Coconut rhizosphere, HDMSCS, CPCRI. d Trichoderma sp., Arecanut rhizosphere, Kumbara. e P-solubilizer, Pepper rhizosphere, ACS, Neerchal
Table 5 Mycorrhizal status in coconut and arecanut cropping sytems

HDMSCS high density multiple species cropping system

\begin{tabular}{ll}
\hline Location & AMF spp. \\
\hline HDMSCS, CPCRI & Funneliformis caledonium, Funneliformis mosseae, Rhizophagus \\
& fasiculatum, Diverssipora eburneum, Gigaspora decipiens, \\
Gi.giganteae, Acaulospora denticulata, A. scrobiculata & G.macrocarpum, Funneliformis mosseae, Rhizophagus clarus \\
Patena & G.macrocarpum, Gi.giganteae, A. denticulata, A. Scorbiculata \\
Patena plot 2 & Rhizophagus fasiculatum, Rhizophagus clarus, Diverssipora eburneum \\
Azad Nagar & G. aggregatum, Rhizophagus fasiculatum, Gi.giganteae, A. denticulata, \\
Neerchal & A. Scorbiculata \\
Velanad & Rhizophagus fasiculatum, G. aggregatum \\
Pulippara & G. aggregatum, Funneliformis mosseae \\
Mogral Puthur & Rhizophagus fasiculatum \\
Keloth & G. aggregatum, Funneliformis mosseae \\
Neerchal & G. aggregatum, Claroideoglomus luteum, Funneliformis caledonium, \\
Veliyamangalam & A. Bireticulata \\
Kumbara & Rhizophagus fasiculatum, Claroideoglomus luteum \\
\hline
\end{tabular}

cropping system [29]. Interestingly, species diversity was more in coconut cropping system than in arecanut cropping system. Studies have reported that the host root structure can influence the mycorrhizal morphology. The relative abundance and frequency of occurrence of the fourteen identified AMF species is depicted in Table 7. An increase in number 
Table 6 AMF diversity indices in coconut and arecanut based cropping systems

\begin{tabular}{llll}
\hline Location & \multicolumn{2}{l}{ Diversity index } & $\begin{array}{l}\text { Species } \\
\text { richness }\end{array}$ \\
\cline { 2 - 3 } & Ds & Hs & \\
\hline Coconut cropping system & & 3.30 & 8 \\
HDMSCS & 0.89 & 1.91 & 3 \\
Patena plot 1 & 0.59 & 2.91 & 4 \\
Patena plot2 & 0.86 & 4.56 & 5 \\
Neerchal & 0.83 & 2.61 & 2 \\
Azadnagar & 0.98 & 2.98 & 2 \\
Velanad & 0.85 & 2.41 & 2 \\
Pulippara & 0.81 & & \\
Arecanut cropping system & & 2.49 & 1 \\
Mogral Puthur & 0.83 & 2.48 & 2 \\
Keloth & 0.83 & 3.44 & 5 \\
Neerchal & 0.91 & 1.39 & 2 \\
Veliyamangalam & 0.81 & 2.50 & 2 \\
Kumbara & 0.84 & & \\
\hline
\end{tabular}

Ds Simpsons diversity index, $H s$ Shannons diversity index of intercrops increased the AMF diversity, this can be due to the fact that an increase in intercrops over a cropping system increases the microbial yield of a place due to the greater availability of root exudates for microbial survival. Overall, Glomeraceae was the dominant family with a frequency of occurrence of $33.5 \%$ and $38.5 \%$ in coconut and arecanut cropping systems respectively. The reports of earlier workers also revealed that Glomus is the dominant genus occurring in Indian soil [16]. Acaulosporaceae dominated next with an occurrence frequency of $14.5 \%$ in coconut and $6.8 \%$ in arecanut cropping systems. AM spp. of the family Gigasporaceae $(5.1 \%)$ and Diversisporaceae $(2.3 \%)$ were observed only in coconut cropping system, while members of the family Clarideoglomeraceae $(1.7 \%)$ were observed only in arecanut cropping system. The relative abundance of the most dominant genus Funneliformis was higher in coconut cropping system (51-52.5\%) when compared to its abundance in arecanut cropping system (19.1\%). It was followed by the second most frequented genus Glomus, with
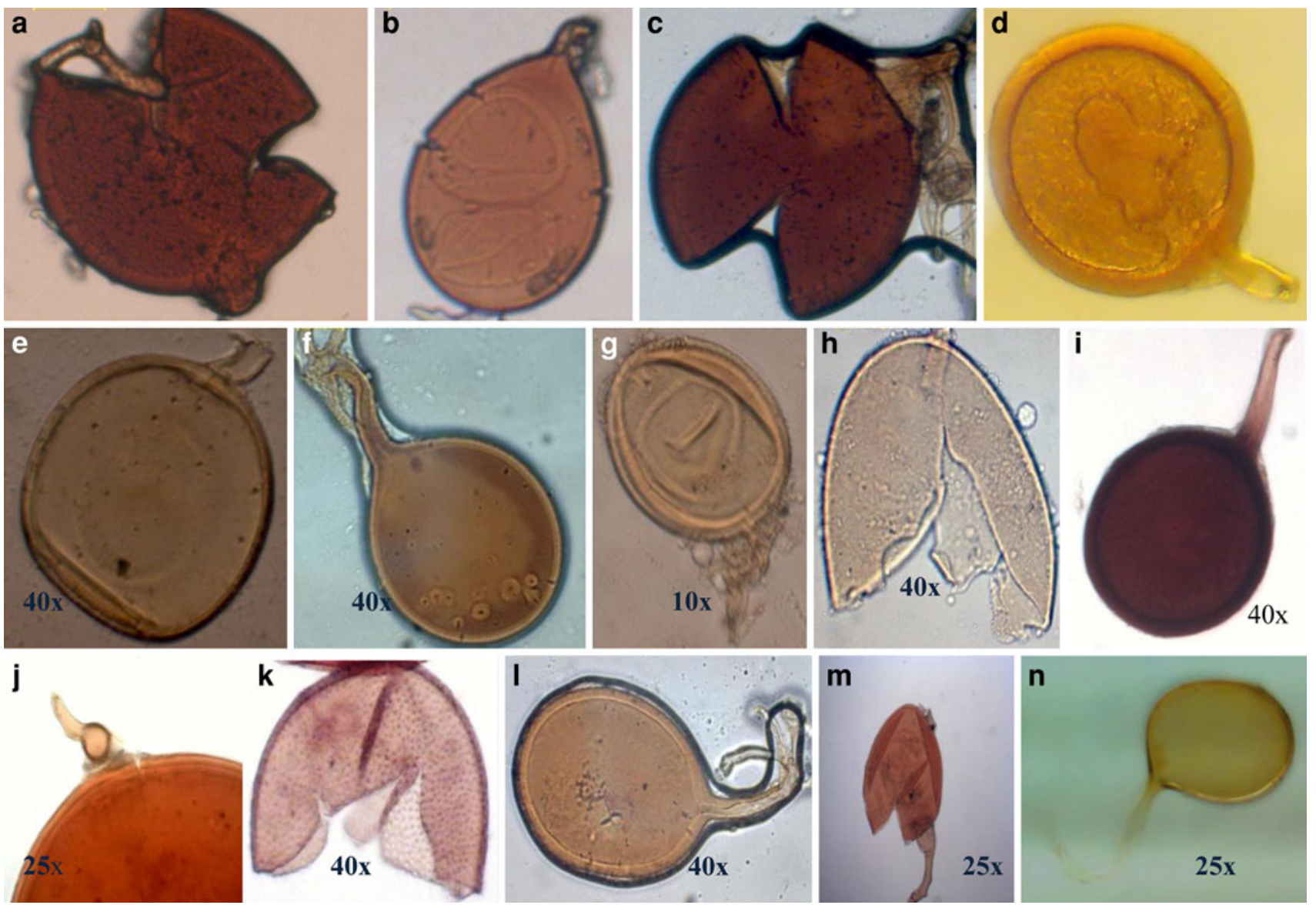

Fig. 2 AMF diversity in coconut and arecanut based cropping systems. a Glomus multicaule, ACS, Neerchal. b Claroideoglomus, luteum, ACS, Keloth. c Glomus sp,ACS, Neerchal. d Glomus sp., CCS, Velanad. e Glomus sp., CCS, Azad Nagar. f Funneliformis, caledonium, Keloth. g Rhizophagus clarus, CCS, Azad Nagar. h Acaulospora laevis, CCS, HDMSCS. I Rhizophagus fasiculatum, CCS, HDMSCS, CPCRI. J Gigaspora giganteae,HDMSCS, CPCRI. k Acaulospora denticulata, HDMSCS,CPCRI. I Diverssipora, eburneum, Azad Nagar. m Gigaspora decipiens, HDMSCS, CPCRI. n Glomus sp., CCS, Velanad 
Table 7 Distribution of AMF in coconut and arecanut cropping systems

\begin{tabular}{|c|c|c|c|c|}
\hline \multirow[t]{2}{*}{ Family/AMF sp. } & \multicolumn{2}{|c|}{$\begin{array}{l}\text { Frequency of } \\
\text { occurrence }(\%)^{\mathrm{a}}\end{array}$} & \multicolumn{2}{|c|}{$\begin{array}{l}\text { Relative } \\
\text { abundance }(\%)^{\mathrm{b}}\end{array}$} \\
\hline & CCS & ACS & CCS & ACS \\
\hline \multicolumn{5}{|l|}{ Glomeraceae } \\
\hline Glomus aggregatum & 3 & 5 & 24.0 & 20.03 \\
\hline G. multicaule & 0 & 9.8 & 0 & 3.94 \\
\hline G.macrocarpum & 8.5 & 0 & 29.5 & 0 \\
\hline Rhizophagus fasiculatum & 5.4 & 5.4 & 33.68 & 2.2 \\
\hline Rhizophagus clarus & 0 & 12 & 0 & 4.8 \\
\hline Funneliformis caledonium & 8.4 & 0 & 52.1 & 0 \\
\hline Funneliformis mosseae & 8.2 & 5 & 51.2 & 19.1 \\
\hline \multicolumn{5}{|l|}{ Claroideoglomeraceae } \\
\hline $\begin{array}{l}\text { Claroideoglomus luteum } \\
\text { Diversisporaceae }\end{array}$ & 0 & 1.7 & 0 & 7.2 \\
\hline $\begin{array}{l}\text { Diverssipora eburneum } \\
\text { Gigasporaceae }\end{array}$ & 2.3 & 0 & 14.5 & 0 \\
\hline G.giganteae & 2.5 & 0 & 3.40 & 0 \\
\hline G.decipiens & 2.6 & 0 & 0.325 & 0 \\
\hline \multicolumn{5}{|l|}{ Acaulosporaeceae } \\
\hline Acaulospora denticulata & 7.9 & 6.8 & 49.1 & 0.78 \\
\hline A. scrobiculata & 5 & 0 & 31.5 & 0 \\
\hline A.laevis & 1.6 & 0 & 10.5 & 0 \\
\hline
\end{tabular}

CCS coconut cropping system, ACS arecanut cropping system

${ }^{a}$ Number of soil samples possessing spores of a particular species divided by total number of samples analysed $\times 100$

b Number of spores of a particular species divided by total number of spores $\times 100$

a relative abundance of $24 \%$ and $20.03 \%$ respectively in coconut and arecanut cropping systems.

Glomus aggregatum (3-5\%), Funneliformis mosseae (5-8.2 \%), and Rhizophagus fasiculatum (5.4\%) were uniformly abundant in both the cropping systems. Diverssipora eburneum (2.3\%), Funneliformis caledonium (8.4\%), G.macrocarpum (8.5\%), Gi.giganteae (2.5\%), Gi.decipiens (2.3\%), A.bireticulata (7.9\%), A.scorbiculata (5\%), and A.laevis (1.6\%) were found to be associated with coconut cropping system. Claroideoglomus luteum (1.7\%), A.scorbiculata (6.8\%) Rhizophagus clarus (12\%), Glomus multicaule $(9.8 \%)$ were found to be associated with arecanut cropping system. Our studies were in tandem with other reports which revealed that differences in host plants may alter the spore population at a particular place [6].

\section{Conclusions}

AMF colonization studies have been reported in coconut cropping systems, but few works throw light on the mycorrhizal association in arecanut cropping systems. This study also reveals that AM Fungal colonization pattern is inversely related to soil $\mathrm{pH}$ and available phosphorous in the soil. Our studies suggest that AMF colonization and species richness is more in coconut cropping systems compared to arecanut cropping systems. It was observed that the spore load and spore diversity were not related and diversity increased with the increase in number of intercrops irrespective of the cropping systems studied. Glomeraceae and Acaulosporaceae families were preponderent in both the cropping systems. However, Gigasporaceae was solely present in coconut cropping system. Glomus aggregatum, Funneliformis mosseae, and Rhizophagus fasiculatum were the uniformly abundant genera in both the cropping systems. Enumeration of the soil microflora revealed that the population of P-solubilizers and AMF spore density were positively correlated in arecanut cropping system, however there was no relationship between soil microflora and AMF species in coconut cropping system.

Acknowledgments The authors thank ICAR, New Delhi for funding the network project on "Application of Micro-organisms in Agriculture and Allied sectors" in which their work was carried out. Ambili K. is grateful for the award of Senior Research Fellowship.

\section{References}

1. Allen MF (1982) Influence of vesicular-arbuscular mycorrhiza on water movement through Boutenia gracilis (HBK) Long ex Steud. New Phytol 91:191-196

2. Bianciotto V, Lumini E, Lanfranco L, Minerdi D, Bonfante P, Perotto S (2000) Detection and identification of bacterial endosymbionts in arbuscular mycorrhizal fungi belonging to family Gigasporaceae. Appl Environ Microbiol 66:4503-4509

3. Bopaiah BM (1991) Soil microflora and VA-mycorrhiza in areca based high density multiple species cropping and monocropping systems. J Plant Crops 18(Supplement):224-228

4. Bray RH, Kurtz LT (1945) Determination of total, organic, and available forms of phosphorus in soils. Soil Sci 59:39-45

5. Christensen H, Jakobsen I (1993) Reduction of bacterial growth by a vesicular-arbuscular mycorrhizal fungus in the rhizosphere of cucumber (Cucumis sativus L.). Biol Fertil Soils 15:253-258

6. Dodd JC, Koomen Arias I, Hayman DS (1990) The management of populations of vesicular-arbuscular mycorrhizal fungi in acidinfertile soils of a savanna ecosystem. Plant Soil 122:229-240

7. Gerdmann JH, Nicolson TH (1963) Spores of mycorrhizal endogone species extracted from soil by sieving and decanting. Trans British Mycol Soc 46:235-244

8. Hanway JJ, Heidel H (1952) Soil analysis method as used in Iowa state college soil testing laboratory. Iowa state coll agric 57:1-31

9. Harikumar VS, Thomas GV (1991) Effect of fertilizers and irrigation on vesicular arbuscular mycorrhizal association in coconut. Philipp J Coconut Stud 16:20-24

10. John TV St (1988) Prospects for application of vesicular-arbuscular mycorrhizae in the culture of tropical palms. Adv Econ Bot 6:50-55

11. Johnston A (1949) Vesicular-arbuscular mycorrhiza in sea island cotton and other tropical plants. Trop Agr (Trinidad) 26:118-121

12. Kjeldahl $\mathrm{J}$ (1883) A new method for the estimation of nitrogen in organic compounds. Z Anal Chem 22:366 
13. Linderman RG, Paulitz TC (1990) Mycorrhizal-rhizobacterial interactions. In: Hornby D, Cook RJ, Henis Y, Ko WH, Rovira AD, Schippers B, Scott PR (eds) Biological control of soil-borne plant pathogens. CAB International, Wallingford, pp 261-283

14. Lloyd H, Zar KH, Karr JR (1968) On the calculation of information-theoretical measures of diversity $[\mathrm{J}]$. Am Midl Nat 79:257-272

15. Meyer JR, Linderman RG (1986) Response of subterranean clover to dual inoculation with vesicular-arbuscular mycorrhizal fungi and a plant-growth-promoting bacterium, Pseudomonas putida. Soil Biol Biochem 18:185-190

16. Muthukumar T, Udaiyan K (2000) Arbuscular mycorrhiza of plants growing in the Western Ghats region, Southern India. Mycorrhiza 9:297-313

17. Olsen S, Cole C, Watanabe F, Dean L (1954) Estimation of available phosphorus in soils by extraction with sodium bicarbonate. USDA Circular Nr 939, US Gov. Print. Office, Washington, D.C

18. Ouimet R, Camire C, Furlan V (1996) Effect of soil K, Ca and $\mathrm{Mg}$ saturation and endomycorrhization on growth and nutrient uptake of sugar maple seedling. Plant Soil 179:207-216

19. Pankhurst CE, Lynch JM (1994) The role of soil biota in sustainable agriculture. In: Pankhurst CE, Doube BM, Gupta VVSR, Grace PR (eds) Soil biota: management in sustainable farming systems. CSIRO Information Sytems, East Melbourne, pp 3-9

20. Philips SJM, Hayman DS (1970) Improved procedure for cleaning roots and staining parasitic and vesicular arbuscular fungi for rapid assessment of infection. Trans British Mycol Soc 55: 158-161

21. Ramesh CR (1984) Root infection and population density of VA mycorrhizal fungi in a coconut based multistoreyed cropping system. Proc Plantation Crops Symposium V (PLACROSYM), pp 548-554

22. Rawther TS, Abraham KJ, Achuthan Nair M, Jayasankar NP (1980) Microbial profiles of arecanut soils under mixed cropping with special reference to arecanut yellow leaf disease. Proc Plantation Crops Symposium II (PLACROSYM), pp 71-75

23. Sanders FE, Sheikh NA (1983) The development of vesicular arbuscular mycorrhizal infection in plant root systems. Plant Soil $71: 223-246$

24. Schübler A, Schwarzott D, Walker C (2001) A new fungal phylum, the Glomeromycota: phylogeny and evolution. Mycol Res 105:1413-1421

25. Secilia J, Bagyaraj DJ (1987) Bacteria and actinomycetes associated with pot culture of vesicular arbuscular mycorrhizas. Can J Bot 33:1069-1107

26. Simpson EH (1949) Measurement of diversity. Nature 163:688

27. Smith KP, Goodman RM (1999) Host variation of interactions with beneficial plant associated microbes. Annu Rev Phytopathol 37:473-491

28. Thomas GV, Ghai SK (1987) Genotype dependent variation in vesicular-arbuscular mycorrhizal colonization of coconut seedlings. Proc Indian Acad Sci Plant Sci 97:289-294

29. Thomas GV, Rajagopal V, Bopaiah BM (1993) VA-Mycorrhizal associations in relation to drought tolerance in coconut. J Plant Crops 21:98-103

30. Toro M, Nedialkova K, Azcon R, Barea JM (1996) Establishment of two rock phosphate-solubilizing bacteria in the rhizosphere of mycorrhizal onion plants and their effect on plant growth in a microcosm. In: Azcon-Aguilar C, Barea JM (eds) Mycorrhizas in integrated systems from genes to plant development. European Commission, Directorate-General XII, Science, Research and Development, Brussels, pp 665-668

31. Walker C, Mize CW, McNabb HS (1982) Populations of endogonaceous fungi at two locations in central Iowa. Can J Bot 60:2518-2529

32. Walkley A, Black IA (1934) An examination of degtjareff method for determining soil organic matter and a proposed modification of the chromic acid titration method. Soil Sci 37:29-37 